\title{
Article
}

\section{The impact of projected changes in climate variability on the reliability of surface water supply in Scotland}

\author{
Afzal, Muhammad, Gagnon, Alexandre S. and Mansell, Martin G. \\ Available at http://clok.uclan.ac.uk/33890/ \\ Afzal, Muhammad, Gagnon, Alexandre S. and Mansell, Martin G. (2015) The \\ impact of projected changes in climate variability on the reliability of surface \\ water supply in Scotland. Water Supply, 15 (4). pp. 736-745.
}

It is advisable to refer to the publisher's version if you intend to cite from the work. http://dx.doi.org/10.2166/ws.2015.027

For more information about UCLan's research in this area go to http://www.uclan.ac.uk/researchgroups/ and search for < name of research Group>.

For information about Research generally at UCLan please go to http://www.uclan.ac.uk/research/

All outputs in CLoK are protected by Intellectual Property Rights law, including Copyright law. Copyright, IPR and Moral Rights for the works on this site are retained by the individual authors and/or other copyright owners. Terms and conditions for use of this material are defined in the policies page. 
The impact of projected changes in climate variability on the reliability of surface water supply in Scotland

Muhammad Afzal, Alexandre S. Gagnon and Martin G. Mansell

\begin{abstract}
Projected changes in precipitation and evapotranspiration under climate change and their impacts on the reliability of six water storage reservoirs and two river intake schemes in Scotland are examined. A conceptual rainfall-runoff model was used to simulate catchment runoff which, together with evapotranspiration, served as inputs into a reservoir model. Outputs from a regional climate model coupled with a weather generator indicate an increase in rainfall variability and evapotranspiration throughout the 21 st century, resulting in a decrease in both the time-based and volumetric reliability of the reservoirs under the assumption of an unchanging demand, albeit with a less drastic reduction for the volumetric approach. It was found that the variability of rainfall had the greatest effect on reservoir reliability, outweighing the positive effect of an increase in total annual precipitation, while evapotranspiration had a lesser impact. A more drastic reduction in reliability was observed for the river intake schemes given their lack of storage capacity. The increase in water demand based on demographic projections further reduced reservoir reliability, especially when monthly variations in demand were taken into account. This paper concludes by suggesting adaptive strategies to deal with the projected changes in the supply and demand for water.
\end{abstract}

Key words: climate change, climate variability, demand, evapotranspiration, Scotland, surface water supply 


\section{INTRODUCTION}

Previous research has identified an increase in the variability of rainfall in the UK (Osborn \& Hulme 2002; Burt \& Horton 2007; Afzal et al. 2015). In Scotland, for example, the variability of rainfall, as measured by the intra-annual variance and the winter to summer (w/s) ratio of precipitation, has increased during the period 1961-2000 (Afzal et al. 2015); the latter due to increasing trends in winter precipitation and decreasing trends in summer rainfall (Barnett et al. 2006). This increase in rainfall variability, notably changes in the temporal distribution of rainfall, together with increasing evaporation rates in summer (Kay et al. 2013), could potentially have negative consequences for water supply systems, especially if the trends observed in recent decades were to continue into the future. Moreover, the reliability of water supply systems depends on the level and seasonal distribution of water demand. Considering that the population of Scotland is projected to increase by approximately $11 \%$ by 2035 (ICE 2012), future increases in water demand are likely. Although Scotland is a water-rich country, there have been reports of water shortages in the past (Marsh \& Anderson 2002). The majority of Scotland's population lives in the central belt where the yield to demand ratio is low in comparison to other parts of the country, and, on the drier East coast, river abstraction for irrigation can also strain local water supplies (Adeloye \& Low 1996). In view of the recent changes in the variability of precipitation and increasing evaporation rates, there is a need to examine whether those trends are projected to continue under climate change and how they might impact on water resources. Hence, this paper aims to examine the impacts of future changes in rainfall variability and evapotranspiration

on the reliability of surface water supplies in various locations across Scotland and to compare the effect of changes in those climatic variables with those associated with changes in future water demand. The focus of this study is on surface water given that it supplies approximately 93\% of public water in Scotland (MacDonald et al. 2005). This paper concludes by suggesting adaptive strategies to deal with the projected changes in the supply and demand for water. 


\section{METHODS}

Rainfall-runoff model A rainfall-runoff (R-R) model was used to simulate catchment runoff which, together with evapotranspiration, served as inputs into a reservoir model. This conceptual R-R model was based on the probability distribution model of Moore (2007), which is widely used in the UK (Kay \& Jones 2012). Daily precipitation and maximum and minimum temperature, which are required to run the model, were obtained from the Met Office Integrated Data Archive System (MIDAS) of the British Atmospheric Data Centre (BADC) (UK Meteorological Office 2006) for weather stations situated in close proximity to six gauged catchments that were used to calibrate and validate the model. Daily wind speed data were also obtained from MIDAS from five of the above weather stations. Daily sunshine duration data, interpolated on a $5 \mathrm{~km}$ resolution grid, were obtained for the period 1961-1990 from the UK Climate Impacts Programme. Daily river flow data were provided by the Scottish Environmental Protection Agency (SEPA) and the Centre for Ecology and Hydrology (CEH). Four characteristics of a reservoir are its storage volume, mean annual inflow, mean annual demand, and its surface area. These data were provided by Scottish Water for six reservoirs, as well as monthly water consumption data for 60 households for the period 2008-2014 derived from 100 supply zones across the country. The selection of the reservoirs was first based on data availability, and then consisted of choosing reservoirs that have experienced

\section{Climate change scenarios}

The latest UK Climate Projections (UKCP09) were used to provide projections for changes in the amount and variability of precipitation and the climatic variables used to estimate evapotranspiration, i.e., maximum and minimum temperature, and sunshine duration. The projections of those climatic variables were then used to simulate catchment runoff using the calibrated model, which was then used as input into a reservoir model to calculate its reliability. The UKCP09 climate change projections are provided for three greenhouse gas (GHG) emission scenarios and for seven overlapping 30-year time periods (Jones et al. 2009). This paper focuses on the medium GHG emission scenario and extends up to the 2080s, the latter referring to the average climatic conditions for the period. 


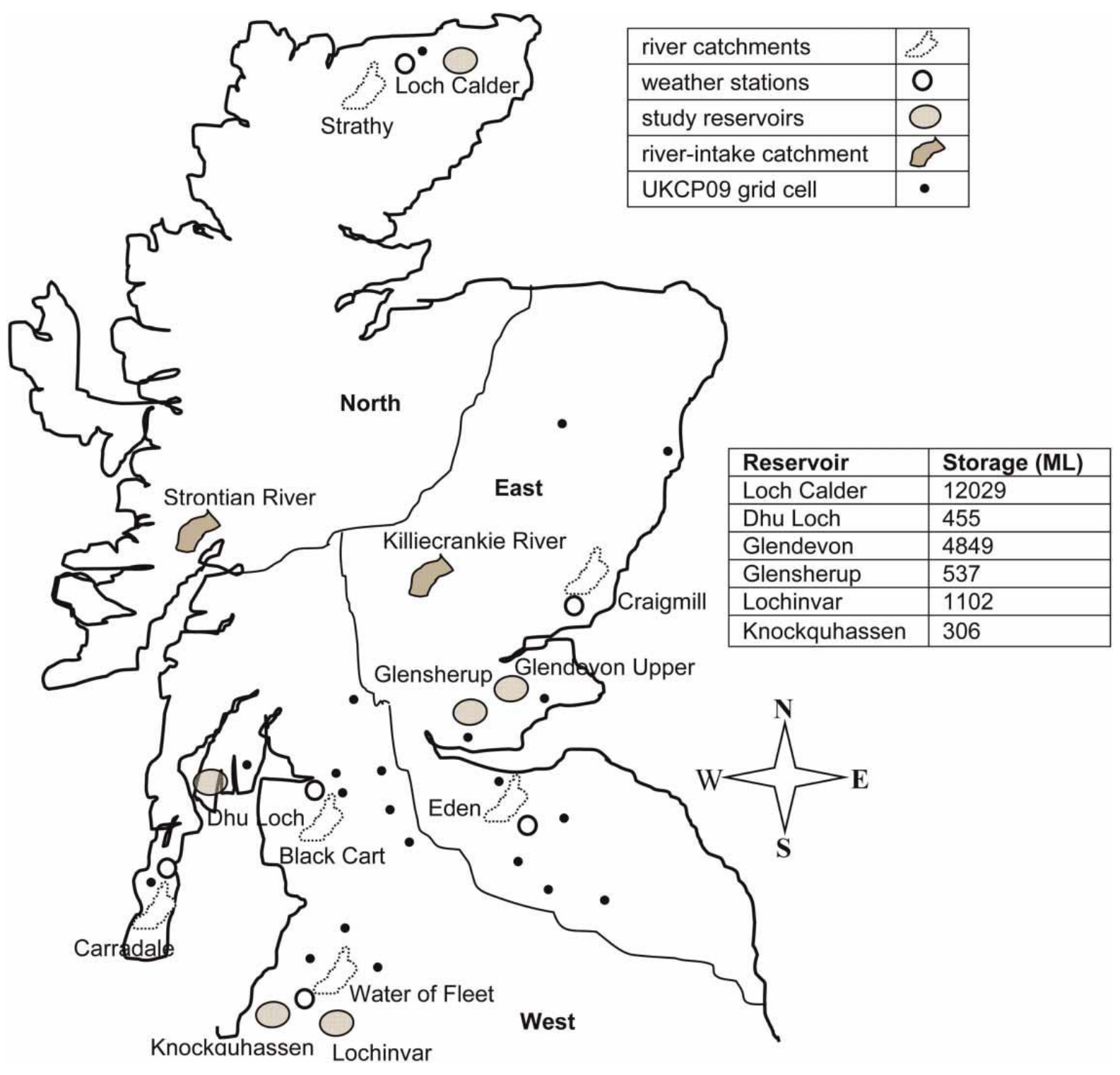

Figure 1: Location of the two river intake schemes and the six water reservoirs together with their storage capacity. The location of the six river catchments and weather stations used to calibrate and validate the R-R model is also shown. 
Table 1: Analysis of the efficiency of the R-R model

\begin{tabular}{|c|c|c|c|c|c|}
\hline Catchments & Surface area $\left(\mathrm{km}^{2}\right)$ & Calibration time period & In NSE & Validation time period & In NSE \\
\hline Strathy at Strathy Bridge & 111.8 & 1991-1997 & 0.66 & 1998-2004 & 0.53 \\
\hline Craigmill Burn at Craigmill & 29.0 & $1987-1993$ & 0.72 & 1994-2000 & 0.64 \\
\hline Eden at Strathmiglo & 26.0 & 1991-1995 & 0.64 & 1996-2000 & 0.58 \\
\hline Black Cart Water at Milliken Park & 103.1 & 1968-1987 & 0.80 & 1988-2006 & 0.71 \\
\hline Carradale at Dippen & 58.5 & 1996-2001 & 0.75 & 2002-2007 & 0.70 \\
\hline Water of Fleet at Rusko & 77.0 & 1988-1992 & 0.77 & 1993-1998 & 0.66 \\
\hline
\end{tabular}

NSE coefficient calculated from daily data.

The R-R model operates at a daily time step. Since the UKCP09 scenarios are available at a monthly time-scale, a weather generator directly available from the UKCP09 interface was used to generate daily time series of the climatic variables. Even though UKCP09 provides scenarios at a $25 \mathrm{~km}$ resolution, the weather generator provides outputs at a $5 \mathrm{~km}$ resolution, as the outputs are given relative to the 1961-1990 baseline time period, which is available at that resolution. Due to the lack of spatial coherence in the climate change scenarios (Kay \& Jones 2012), only one UKCIP grid cell was considered per catchment. The cells covering the reservoirs or located closest to the river intake schemes were selected. Most catchments are small with a spatial area varying from only 0.56 to $22.83 \mathrm{~km} 2$ and hence in many cases only one grid cell was required to cover the extent of both the reservoir and its catchment. When running the weather generator, 100 realisations of the daily time series were generated in order to account for the uncertainty associated with the scenarios with the $50 \%$ probability level selected.

Climate change projections were obtained for 30 grid cells, corresponding to the location of the eight catchments (six reservoirs and two river intake schemes) and the 22 weather stations analysed in Afzal et al. (2015).The projections for the grid cells corresponding to the weather stations were not used to run the R-R model but only to examine how rainfall variability and evapotranspiration are projected to change under climate change. These grid cells were added to the analysis to have climate change projections that are more representative of Scotland as a whole and not only to the eight case study sites, but also to put the projections in the context of the climatic changes experienced over the last few decades. 

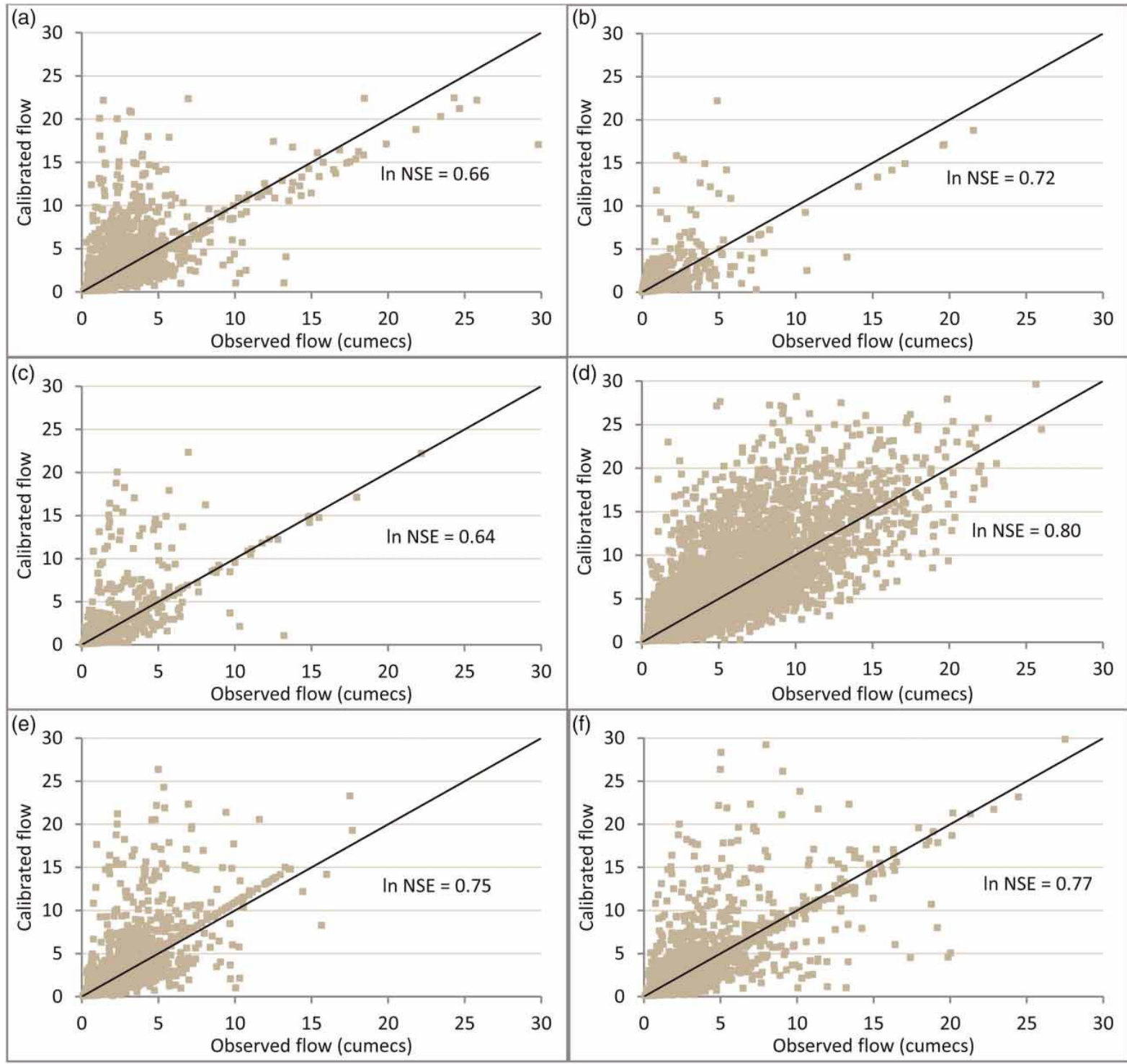

Figure 2: The relationship between the simulated and observed flow of the Strathy (a), Craigmill (b), Eden (c), Black Cart (d), Carradale (e), and Water of Fleet (f) rivers.

\section{Rainfall variability and evapotranspiration:}

Rainfall variability was measured by three parameters: w/s ratio, intra-annual variance, and intra-annual cumulative sum (CUSUM) range. The intra-annual CUSUM range is a measure of the temporal distribution of rainfall, with a large value indicating that rainfall is more concentrated over a short period, while a small value means that rainfall is more uniformly distributed throughout the year (Afzal et al. 2015). Grass reference potential evapotranspiration (PE) was estimated using the modified Penman-Monteith equation (Allen et al. 1998). As UKCP09 does not provide projections for wind speed, a constant value of $2.5 \mathrm{~m} / \mathrm{s}$ was used on the basis of the mean annual wind speed measurements reported in Peacock et al. (2008). 
Rainfall variability and evapotranspiration rates were computed for the baseline time period and for each of the future 30-year time periods at the 30 UKCP09 grid cells mentioned above

\section{Reservoir model and reliability analysis:}

The operation of the reservoirs was modelled using a simple tank model with the storage volume of a reservoir, $\mathrm{S}$, at time step $\mathrm{t}+1$ calculated using the following equation:

$$
\begin{aligned}
& S_{t+1}=S_{t}+Q_{t}-D_{t}+\left(P_{t}-E_{t}\right) A_{t}\left(\text { if } S_{t}<S_{\max }\right) \\
& S_{t+1}=S_{\max } \text { otherwise }
\end{aligned}
$$

where Qt and Dt are the inflow and outflow into and out of the reservoir, respectively, Smax is the maximum storage volume, and At is the surface area of the reservoir. Pt _ Et refers to net precipitation (precipitation - evaporation) on the reservoir surface with Et estimated by multiplying Pet (defined above) by a factor of 1.1 (Finch \& Calver 2008). The reservoir area is a function of the storage volume at time $t$ as well as the topography. Using values of surface area and storage volume of the six reservoirs used, an approximate relationship between reservoir area (ha) and its storage volume (ML) was established

$$
A_{t}=0.07 S_{t}^{0.86}
$$

This relationship was assumed to represent the general topography of reservoir basins. The model performed two iterations with the initial volume for the second iteration set at the volume at the end of the first iteration to avoid any bias from the starting volume. In Equation (1), Dt was determined from the demand ratio, i.e., the daily demand in relation to mean annual inflow, except that it was reduced when the volume fell below $60 \%$ according to the relationship described in Table 2. Both the time-based and volumetric reliability of the reservoirs was calculated. The time-based reliability measures the frequency of a water shortage without considering its magnitude, while the volumetric reliability quantifies the severity of the failure (McMahon \& Adeloye 2005). The time-based reliability, RT, of the reservoirs as well as the reliability of the river intake schemes was calculated using: 


$$
R_{T}=\left(1-\frac{N_{f}}{30 \times 365}\right) * 100
$$

where $\mathrm{Nf}$ is the number of failure days during the 30 -year simulation period. In the case of a reservoir a 'failure' was arbitrarily defined as having occurred when the reservoir volume fell below $30 \%$ of its capacity, which is the threshold often selected in drought management plans for imposing the highest level of water restrictions (Kiem \& Franks 2003). For the river intake schemes a failure was logged when the Q95, calculated over the period 1961-1990, was reached. The Q95 is a widely used threshold to guide abstraction and consent policies in the UK (Arnell et al. 2014).

Table 2: Actual water supply as a function of demand (from Kiem \& Franks 2003)

\begin{tabular}{ll} 
Percentage of total storage & Proportion of normal demand \\
\hline $50-60$ & 0.95 \\
$40-50$ & 0.90 \\
30 & 0.85 \\
$<30$ & 0.75 \\
\hline
\end{tabular}

The volumetric reliability, Rv, which measures the proportion of the water supplied to the total demand, was calculated using:

$$
R_{v}=1-\frac{\sum_{j \in f}\left(D_{t}-D_{t}^{\prime}\right)}{\sum_{j \in N} D_{t}}
$$

where Dt and Dt' are the water demand and the actual demand supplied, respectively, on any given day $\mathrm{t}$; $\mathrm{f}$ is the number of days when the supply did not meet the normal demand, and $\mathrm{N}$ is the number of days during the simulation period (McMahon \& Adeloye 2005).

\section{RESULTS AND DISCUSSION}

\section{Climate change scenarios:}


It was found that total annual precipitation and the variability of rainfall are projected to increase throughout the $21^{\text {st }}$ century, with the increase in variability being of larger magnitude

than precipitation totals. Figure 3 shows the increase in the three measures of variability relative to the 1961-1990 baseline. Although rainfall variability decreased slightly in the 2070s in comparison to the previous 30 -year time period, an overall increase is projected for the $21 \mathrm{st}$ century. These findings are a continuation of the increasing trends in the same three measures of variability observed in recent decades by Afzal et al. (2015) at the same 22 locations across Scotland, and agree with the increase and decrease in winter and summer precipitation, respectively, projected by Thompson (2012) under climate change for upland catchments located in south-western Scotland.

Evapotranspiration rates are also expected to increase in Scotland throughout the 21st century (Figure 4). This is consistent with Kay et al. (2013), who noted that the recent increase in evaporation observed across Britain is projected to continue under climate change. The increase in evapotranspiration was found to be associated with an increase in sunshine duration, particularly in the East, where the increase is expected to be greater than in the West.

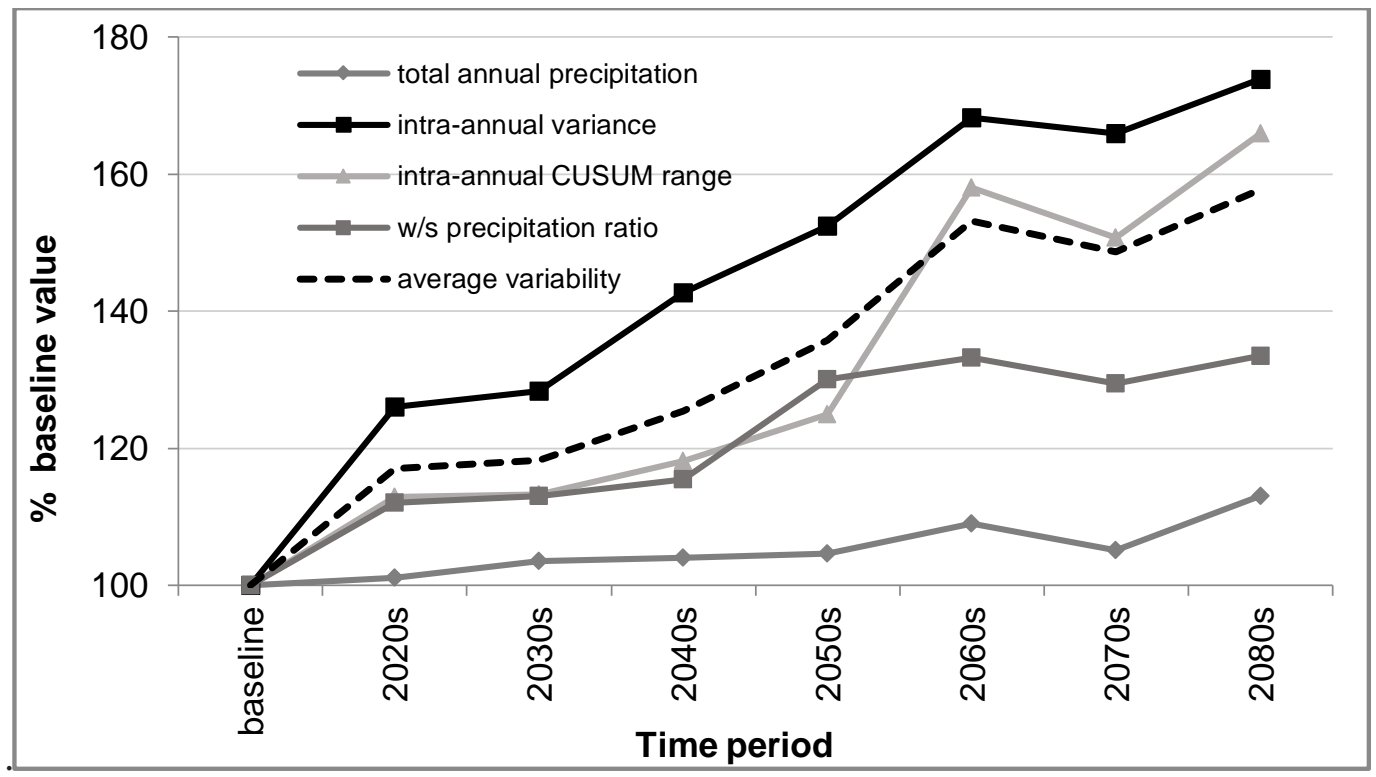

Figure 3: Projected changes in total annual precipitation and in the variability of rainfall for the $50 \%$ probability level of the UKCP09 medium GHG emission scenario. Average variability refers to the average of the three measures of variability. The projections are for the average of 22 UKCP09 grid cells. 


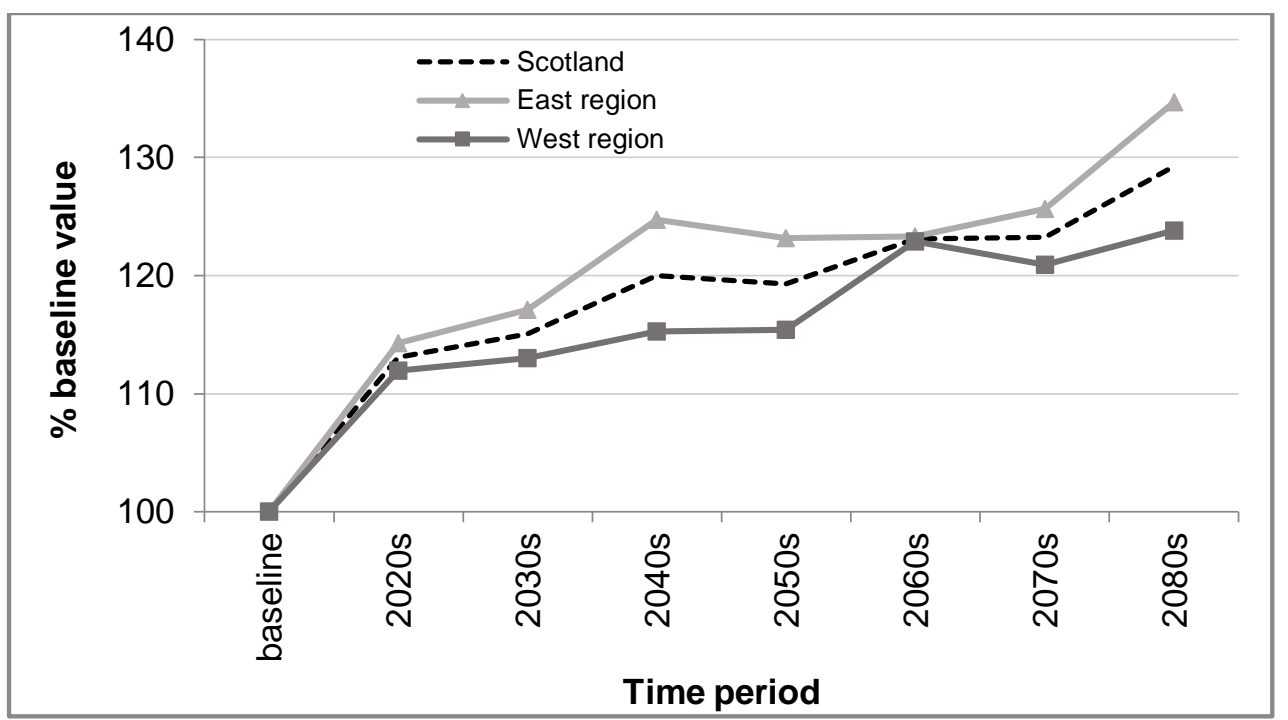

Figure 4. Projected changes in evapotranspiration for the 50\% probability level of the UKCP09 medium GHG emission scenario for the same grid cells.

\section{Reliability of surface water supplies under climate change}

To find the effect of rainfall variability on the reservoir reliability, the reliability of the case study reservoirs was calculated using the mean and the individual characteristics of the case study reservoirs. In addition to the volumetric reliability, time-based reliability, resilience and vulnerability of the reservoirs was calculated under all projected time periods.

\section{Reliability of reservoirs under constant water demand}

This section of the results section presents the results of all the measures of reliability under constant water demands. Figure 5 illustrates the projected changes in the volumetric reliability of a notional reservoir having the mean storage and demand ratios of the six case study reservoirs. The reliability of the reservoir was calculated in the first instance using projections of both precipitation and evapotranspiration, but assuming a constant water demand. Using these criteria, a slight decrease in volumetric reliability is seen throughout the $21^{\text {st }}$ century with the reliability falling to below $98 \%$ of its $1961-1990$ value in the 2080 s. The average reliability of the reservoir was above $99 \%$ during the period 1961-1990, which is similar to the average reliability of reservoirs in the United States, for example (Matonse et al., 2013).It was found that the effect of changes in evapotranspiration on reservoir reliability was small, although significant compared to the effect of changes in rainfall. When the projected increase in evapotranspiration was applied with the baseline precipitation, the average volumetric reliability of the notional reservoir decreased by less than $1 \%$ in the 2080 s (Figure 6). The 
effect of changes in precipitation amounts was also found to be marginal as shown by increasing the baseline rainfall data by the projected trend in precipitation without changing the temporal distribution of rainfall from its 1961-1990 value. This demonstrates it is the variability of precipitation which is important determining the reliability of reservoirs, rather than the amount of precipitation or evaporation.

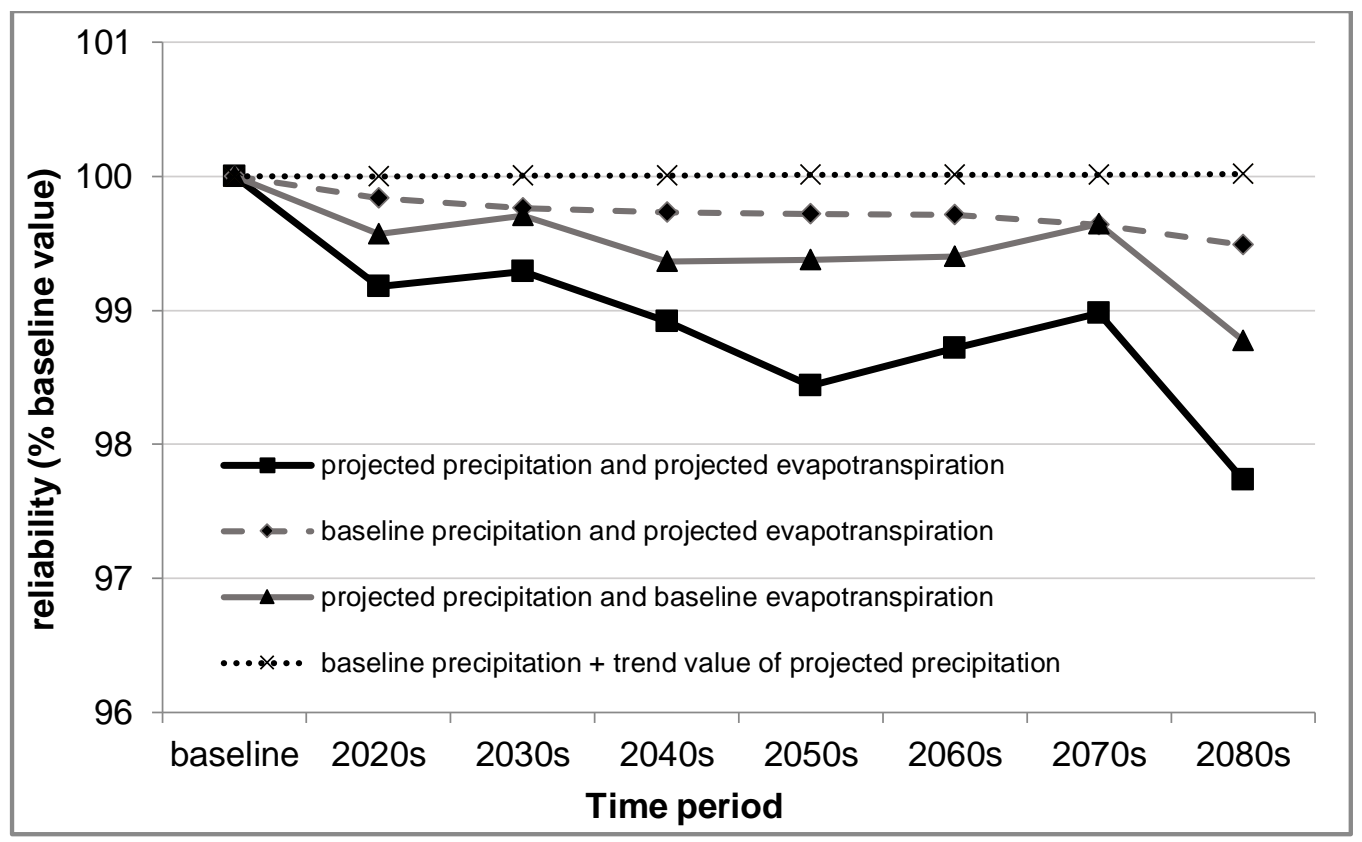

Figure 5. Projected changes in the volumetric reliability of a notional reservoir having the mean storage and demand ratio of the six actual reservoirs; the projections assume an unchanging water demand; they are for the 50\% probability level of the UKCP09 medium GHG emission scenario and are relative to the 1961-1990 baseline time-period.

Figure $6.4 \mathrm{a}$ shows the projected changes in the time-based reliability of individual reservoirs. It reveals an overall decrease in reliability at all six reservoirs although the decrease is not always consistent from one 30-year period to the next. The largest decrease in reliability is projected for the 2080s for the Lochinvar, Glensherup, and Dhu Loch reservoirs where it decreases to approximately $75 \%$ of baseline conditions, while it falls to between $80 \%$ and $90 \%$ of baseline conditions for the other three reservoirs. When considering the volumetric definition, the largest decrease in reliability is projected for the Glensherup and Glendevon reservoirs, but not decreasing below $90 \%$ of baseline conditions, and it only decreases by up to $2 \%$ at the other reservoirs (Figure 7). 

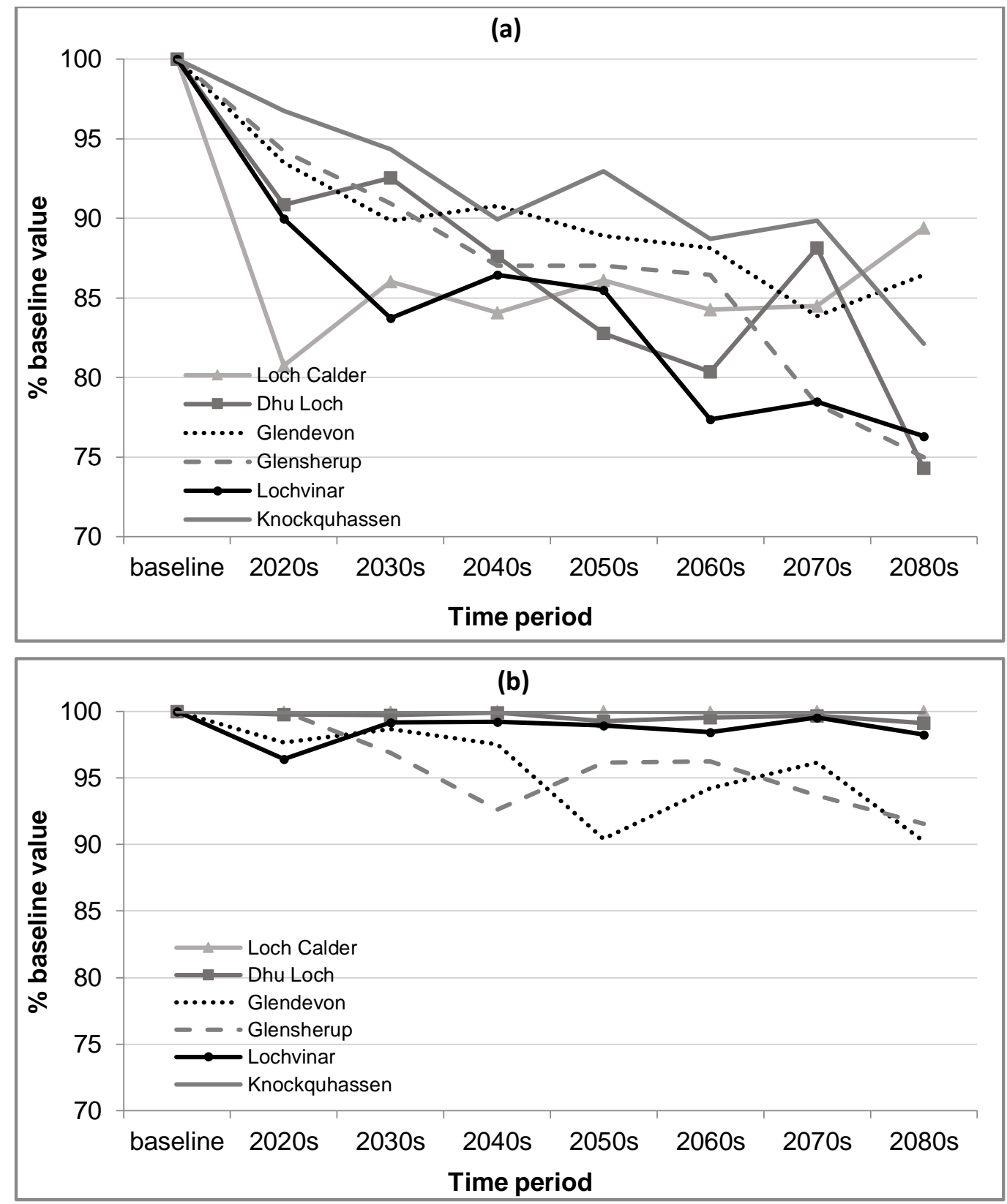

Figure 6. Projected change in the time-based (a) and volumetric (b) reliability of the six reservoirs using the projected changes in precipitation (including its variability) and evapotranspiration. As in Figure 6.3, the projections assume an unchanging water demand; they are for the 50\% probability level of the UKCP09 medium GHG emission scenario and are relative to the period 1961-1990.

The two river intake schemes also indicate a decrease in reliability under climate change. More than $40 \%$ of operational sources in Scotland are from schemes that extract water directly from 
rivers and burns. The two selected sites are located in the Highlands, since it is the Scottish region with the highest percentage of water supplies originating from such schemes (Wright, 1995). Figure 6.5 shows that under the assumption of an unchanging demand a decrease of up to approximately $15 \%$ in the reliability of the two river uptake schemes is projected (Figure6.5a). This is probably due to a reduction in summer river flow (Figure 7b); Capell et al. (2013) also reported a reduction in summer low flows in the Scottish Highlands under climate change.
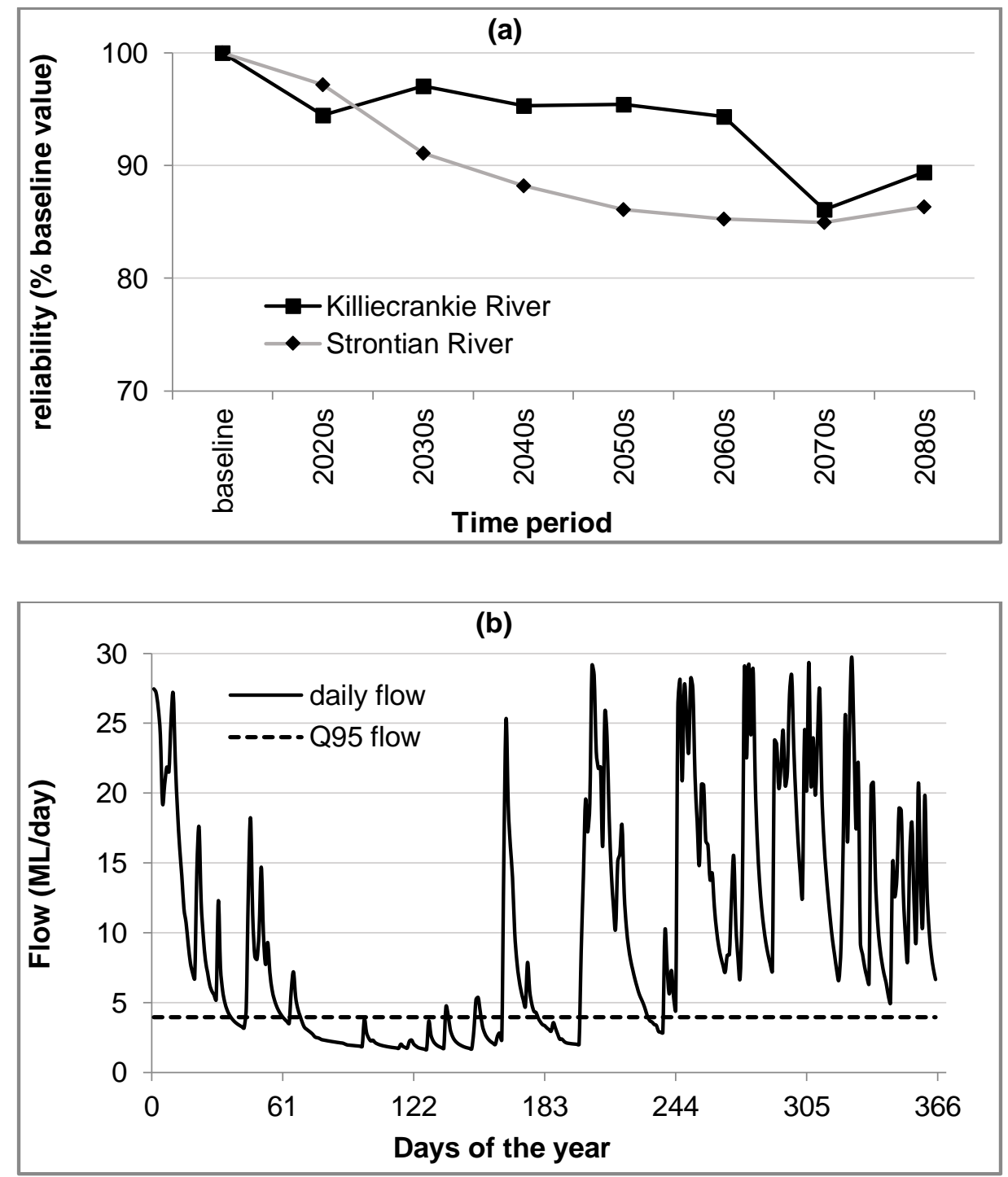

Figure 7. Reliability of Killiecrankie and Strontian river intake schemes under constant water demand for the 50\% probability level of the UKCP09 medium GHG emission scenario in comparison to the period 1961-1990 (a); and hydrograph of the Killiecrankie River for a year in the 2080s (b). 
Overall the reliability of surface water supplies in Scotland is projected to decrease under climate change despite an increasing trend in total annual precipitation. This is because the increase in precipitation is outweighed by changes in the temporal distribution of rainfall, i.e. wetter winters and drier summers, and potentially because the increase in winter rainfall is projected to be in the form of extreme events (Sanderson et al., 2012), which do not generally contribute as much to storage as an increase in the number of wet days, for example. The analysis also highlighted the difference in the projected changes in reliability between the timebased and the volumetric approach with the decrease in volumetric reliability being more modest than that of time-based reliability. Nonetheless, the volumetric reliability is still projected to fall by about $10 \%$ of baseline conditions at two reservoirs in the East under climate change.

To find the reliability of the water supply system, other methods of detecting reliability like resilience and vulnerability were also applied. The resilience is most commonly used term to find how long the water supply system takes to recover after each failure (Fowler et al., 2003). The resilience of the water supplies depends on the number of continuous sequences of failures and total duration of the failures. The analysis carried on case study reservoirs shows that the mean resilience of the reservoirs has increased in comparison to the baseline period, up-to $19 \%$ in the 2080s (Figure 8).

These results show that due to the increased rainfall variability, reservoirs will take longer to recover after each failure. Overall this change in resilience is not consistent from one 30-year period to the next (Figure 8). Like rainfall variability, the resilience of the reservoirs increased slightly in the 2070s in comparison to the previous period but increased in the 2080s. The reservoir vulnerability which is generally defined as the average of maximum shortfall occurring in each of the continuous failure periods, (McMahon and Adeloye, 2005) showed no continuous increase as was observed in the resilience of the case study reservoirs. This analysis shows that the resilience is slightly more sensitive to the climatic variability than vulnerability.

\section{Sensitivity of reservoir reliability to change in demand}

In the above analysis, the effect of climate change on reservoir reliability was estimated without considering potential changes in water demand. However, the demographic projections are 
expected to lead to an increase in water demand given the close association between the demand for water and population size (Wright, 1995). For this reason, the analyses were repeated by considering an increase in water demand of $0.41 \%$ per year. This figure was based on the population projections for Scotland for up to 2035 (ICE, 2012), and agrees closely with the increasing trend in water demand that Scotland has experienced over the past 25 years (Figure 9).

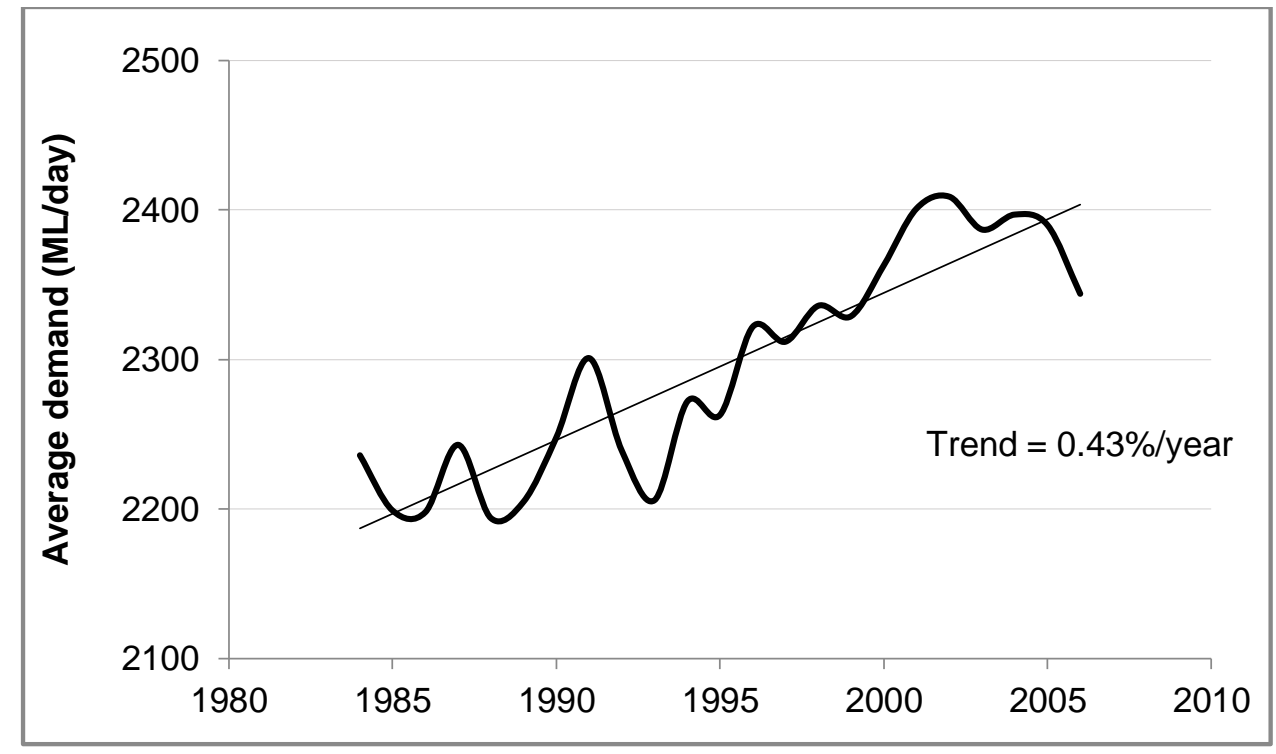

Figure 8: Water demand in Scotland, this data was obtained from the Scottish Environment database (SESO, 2013).

The increase in water demand has been significantly higher than population growth during the period 1983/1984-2005/2006. This is because domestic water use accounts for approximately $40 \%$ of water demand in Scotland (Scottish Water, personal communication, July 2013). This analysis was limited to domestic water bearing in mind that the demand for water by the industrial, energy, and agricultural sectors might also vary in the future. Nonetheless, between 2002/03 and 2012/13, domestic water consumption increased by $7 \%$ in Scotland, whilst non domestic consumption decreased by 19\% (Scottish Water, personal communication, July 2013); and a study in England and Wales projected a declining industrial use for water and a rising trend in household water consumption (Subak, 2000).

As expected, figure 9 shows that an increase in water demand decreases further the reliability of the storage reservoirs. However, the decrease in reliability based on a projected increase in annual water demand is of smaller magnitude than the effect of changes in the climatic variables. Water 
demand, however, is not constant throughout the year and varies seasonally. Figure 6.8 shows the monthly variations in the domestic demand for water in Scotland. The difference between the month with the highest demand (June) and the month with the lowest demand (January) is only $8 \%$, and such intra-annual variation in the demand for water decreases further the reliability of the storage reservoirs (Figure 10).

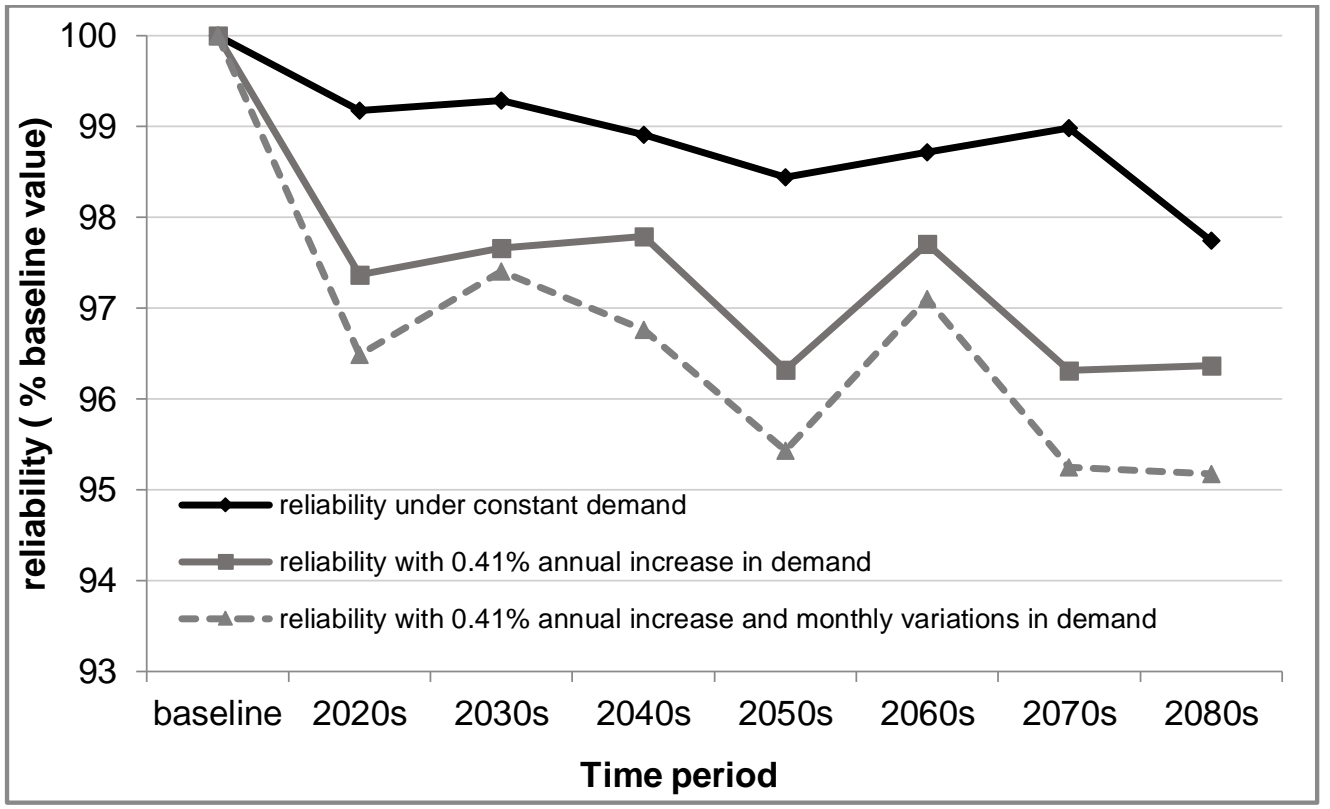

Figure 9: The effect of increasing demand and monthly variations of demand on the reliability of the six reservoirs for the 50\% probability level of the UKCP09 medium GHG emission scenarios in comparison to the period 1961-1990. 


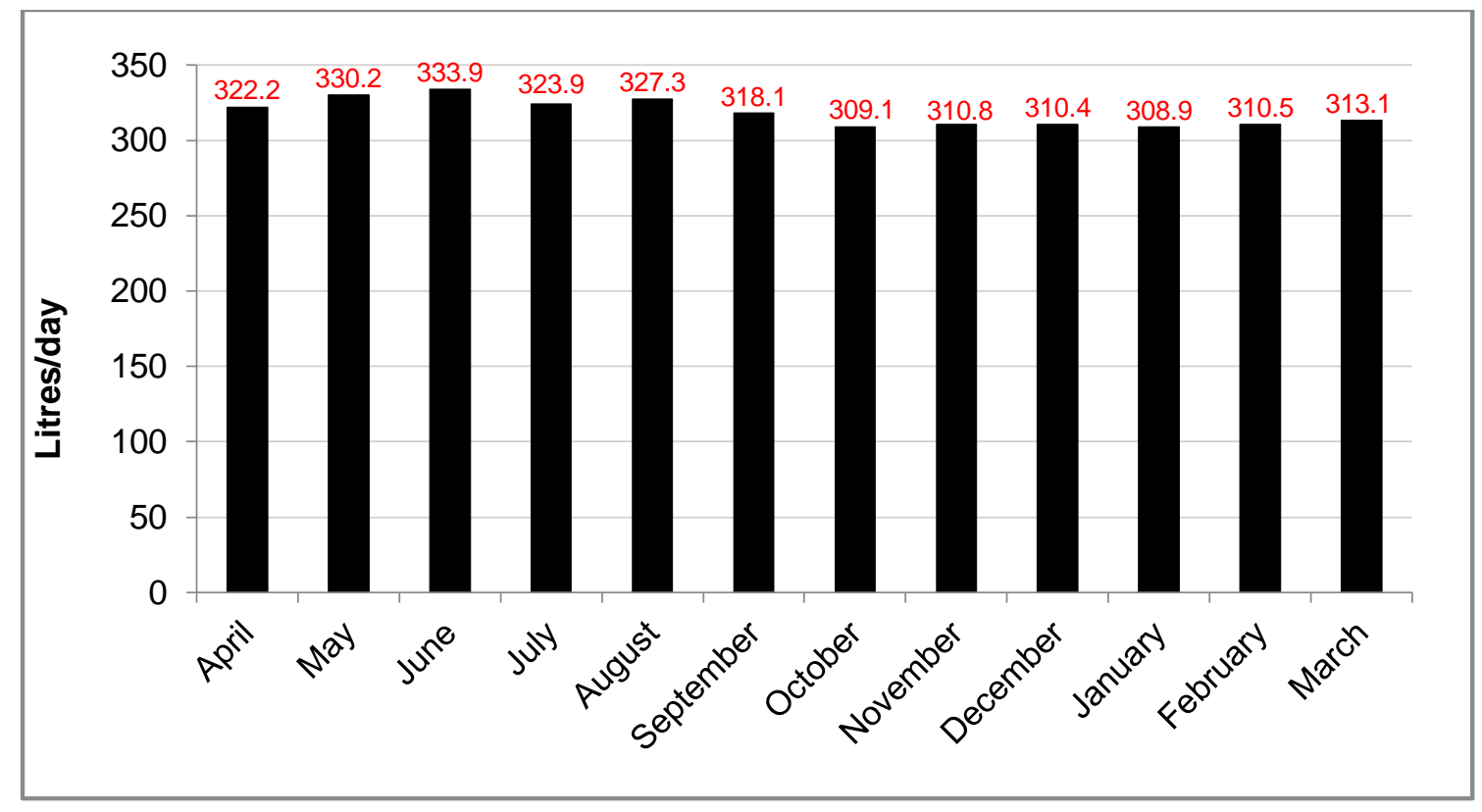

Figure 10: Average monthly water demand for 60 households across Scotland for the period April 2008 - March 2014.

\section{Sensitivity of reservoir reliability to change in storage:}

A sensitivity analysis of reservoir storage volume was carried out to see the future needs of water storage capacity in context to the projected changes in climatic variability. To achieve this research objective, the analysis was carried using the following steps:

- Baseline reliability was calculated using a constant storage and demand ratio.

Future reliability was calculated over all time period and storage ratio was adjusted until the baseline value reliability was achieved. The difference shows the change in storage required to offset the effect of climatic variability

○ The analysis was repeated over all time periods and for all six reservoirs. Then the average of change in storage ratio of the six reservoirs was plotted.

The figure 11 shows the required storage capacity of all selected reservoirs considering the future projected changes in climatic variability. The analysis clearly indicates the reservoir storage capacity needed to counteract future climatic variability. The analysis shows that even though the reliability decreases overall by about $20 \%$ by the 2080 s a drastic increase in storage ratio is required $(50 \%)$ to maintain the same reliability. 


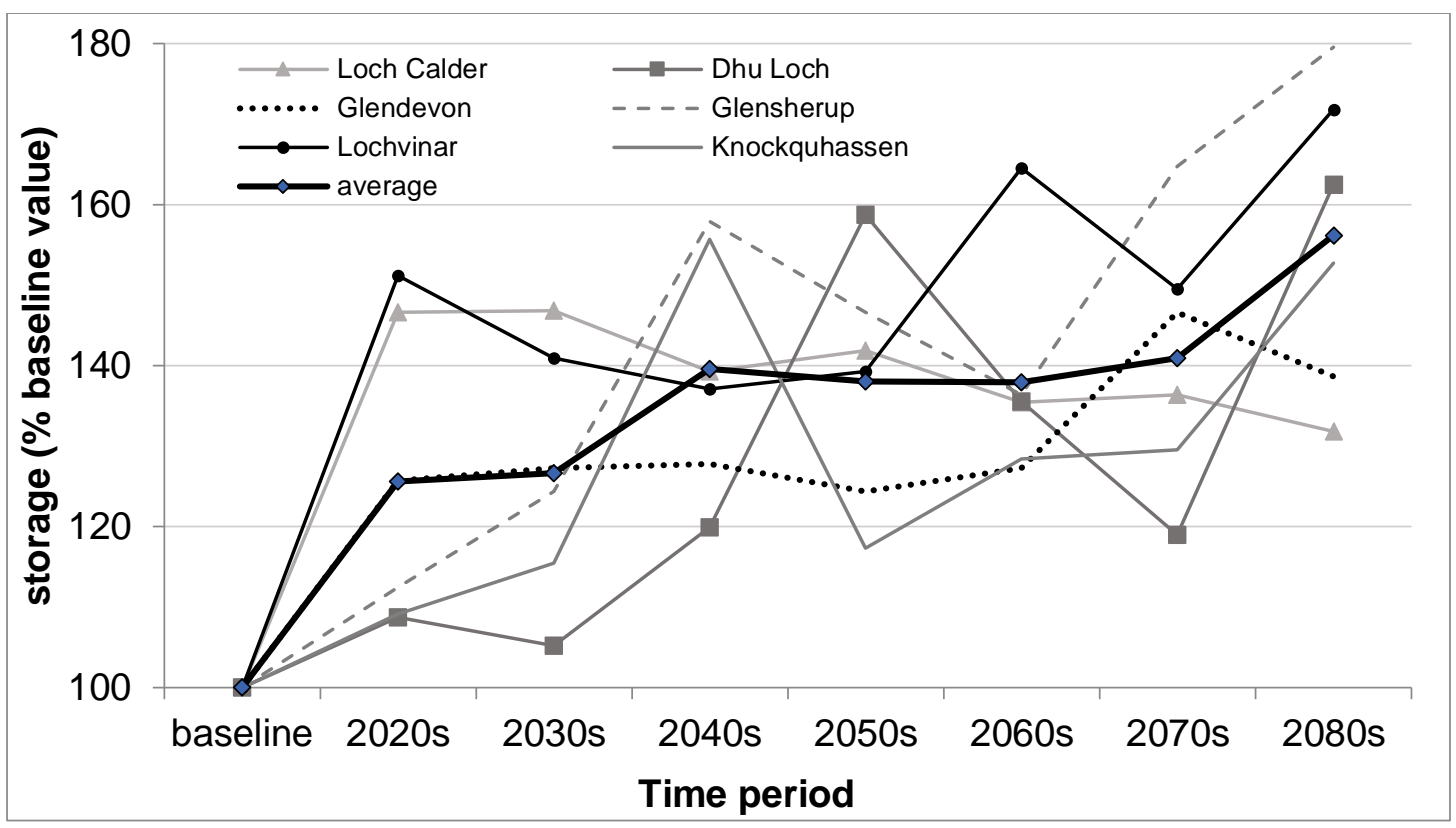

Figure 11: Projected changes in the storage capacity of the six case study reservoirs under increasing climatic variability for the 50\% probability level of the UKCP09 medium GHG emission scenarios, in comparison to the period 1961-1990.

\subsection{Discussion and conclusion}

Even though total annual precipitation is projected to increase under climate change, the reliability of six storage reservoirs from the three climatological regions of Scotland and two river intake schemes is projected to decrease; primarily as a result of changes in the variability of rainfall but with changes in evapotranspiration and water demand playing a significant role. Water supplies may not be at high risk in Scotland in comparison to other countries, but it is possible that the population of Scotland will increase further in the coming decades as a result of migration pressures due to the effects of climate change in less fortunate countries. New investment will be required if the demand for water is not met through greater water efficiency or by alternative sources to traditional reservoirs such as rainwater harvesting systems (Zhang and $\mathrm{Hu}, 2014)$, or by reducing evaporation from the reservoirs by spreading an ultra-thin layer of organic molecules on their surface (Alamaro et al., 2012).

The above analyses have some limitations, however. Projections for wind speed were not available and hence future estimates of evapotranspiration were calculated using a constant wind speed value. Trend analyses indicate a decrease in wind speed over the past few decades in Scotland (Barnett et al., 2006), in agreement with observations seen in many parts of the 
globe (McVicar et al., 2012). If those trends were to continue, a decrease in wind speed would decrease the magnitude of the projections of evaporation and consequently slightly decrease the reduction of reliability that is projected. However, recent analyses by the authors have revealed that evapotranspiration in Scotland is more sensitive to changes in sunshine duration and temperature than to wind speed. Also, an increase in the atmospheric concentration of carbon dioxide could cause plant stomata to close and not considering this change in canopy resistance could also result in an overestimation of $P E$ (Bell et al., 2011).

In addition, this study considered that the current land use management practices will continue in the future. It also projected water demand until the 2080s, whereas demographic projections are available up to 2035. Population projections are highly uncertain and extrapolating them further increases the uncertainty. In addition, during an 80-year period population behaviour towards water use is likely to change. Nonetheless, this part of the analysis aimed at putting into context the effects of changes in climate variability on reservoir reliability by comparing them with the impact of changes in water demand on reservoir reliability.

\section{ACKNOWLEDGEMENTS:}

The authors thank the BADC for providing the climatic data and CEH and SEPA for the river flow data. We are also thankful to Dr Owen Bramwell and Mary Lynch from Scottish Water for providing water demand data and information about the characteristics of the case study reservoirs. A. S. Gagnon acknowledges financial support from the Scottish Alliance for Geoscience, Environment and Society (SAGES).

\section{References:}

Adeloye, A. J. \& Low, J. M. 1996 Surface-water abstraction controls in Scotland. Journal of the Chartered Institution of Water and Environmental Management 10 (2), 123-129.

Afzal, M., Gagnon, A. S. \& Mansell, M. G. 2015 Changes in the variability and periodicity of precipitation in Scotland. Theoretical and Applied Climatology 119 (1-2), 135-159.

Alamaro, M., Emanuel, K. \& Langer, R. S. 2012 Surface film distribution system and method thereof. In Google Patents. 
Allen, R. G., Pereira, L. S., Raes, D. \& Smith, M. 1998 Crop Evapotranspiration - Guidelines for Computing Crop Water Requirements. Food and Agriculture Organization (FAO) of the United Nations, FAO, Rome.

Arnell, N. W., Charlton, M. B. \& Lowe, J. A. 2014 The effect of climate policy on the impacts of climate change on river flows in the UK. Journal of Hydrology 510, 424-435.

Barnett, C., Hossell, J., Perry, M., Procter, C. \& Hughes, G. 2006 Patterns of climate change across Scotland: Technical Report. Scotland \& Northern Ireland Forum for Environmental

Research, Edinburgh.

Bell, V. A.,Gedney, N.,Kay,A. L., Smith, R. N. B., Jones, R.G.\& Moore, R. J. 2011 Estimating potential evaporation from vegetated surfaces for water management impact assessments using climate model output. Journal of Hydrometeorology 12 (5), 1127-1136.

Burt, T. P. \& Horton, B. P. 2007 Inter-decadal variability in daily rainfall at Durham (UK) since the 1850s. International Journal of Climatology 27, 945-956.

Capell, R., Tetzlaff, D. \& Soulsby, C. 2013 Will catchment characteristics moderate the projected effects of climate change on flow regimes in the Scottish Highlands?

Hydrological Processes 27 (5), 687-699.

Finch, J. \& Calver, A. 2008 Methods for the Quantification of Evaporation from Lakes. CEH, Wallingford, Oxfordshire.

ICE 2012 The State of the Nation. Water 2012. Institution of Civil Engineers, London. Jones, P. D., Kilsby, C. G., Harpham, C., Glenis, V. \& Burton, A. 2009 UK Climate Projections Science report: Projections of Future Daily Climate for the UK from the Weather Generator. University of Newcastle, Newcastle.

Kay, A. L., Bell, V. A., Blyth, E. M., Crooks, S. M., Davies, H. N. \& Reynard, N. S. 2013 A hydrological perspective on evaporation: historical trends and future projections in Britain. Journal of Water and Climate Change 4 (3), 193-208. 
Kay, A. L. \& Jones, R. G. 2012 Comparison of the use of alternative UKCP09 products for modelling the impacts of climate change on flood frequency. Climatic Change 114 (2), 211230.

Kiem, A. S. \& Franks, S. W. 2003 Elevated drought risk due to multi-decadal climate variability. In: Water Resources Systems - Hydrological Risk, Management and Development (G. Bloschl, S. Franks, M. Kumagai, K. Musiake \& D. Rosbjerg, eds). IAHS Press, Centre for Ecology and Hydrology, Wallingford, Oxfordshire, UK, pp. 165-172.

Krause, P., Boyle, D. P. \& Bäse, F. 2005 Comparison of different efficiency criteria for hydrological model assessment. Advances in Geosciences 5, 89-97.

MacDonald, A. M., Robins, N. S., Ball, D. F. \& Dochartaigh, B. E. O. 2005 An overview of groundwater in Scotland. Scottish Journal of Geology 41, 3-11.

Marsh, T. J. \& Anderson, J. L. 2002 Assessing the water resources of Scotland perspectives, progress and problems. Science of the Total Environment 294 (1-3), 13-27.

McMahon, T. A.\&Adeloye, A. J. 2005 Water Resources Yield. Water Resources Publications, LLC, Highlands Ranch, Colorado.

McVicar, T. R., Roderick, M. L., Donohue, R. J., Li, L. T., Van Niel, T. G., Thomas, A., Grieser, J., Jhajharia, D., Himri, Y., Mahowald, N. M., Mescherskaya, A. V., Kruger, A. C.,

Rehman, S. \& Dinpashoh, Y. 2012 Global review and synthesis of trends in observed terrestrial near-surface wind speeds: implications for evaporation. Journal of Hydrology $416,182-205$.

Moore, R. J. 2007 The PDM rainfall-runoff model. Hydrology and Earth System Sciences 11 (1), 483-499.

Nash, J. E. \& Sutcliffe, J. V. 1970 River flow forecasting through conceptual models part Ia discussion of principles. Journal of Hydrology 10 (3), 282-290. 
Osborn, T. J. \& Hulme, M. 2002 Evidence for trends in heavy rainfall events over the UK. Philosophical Transactions. Series A, Mathematical, Physical, and Engineering Sciences 360 (1796), 1313-1325.

Peacock, A. D., Jenkins, D., Ahadzi, M., Berry, A. \& Turan, S. 2008 Micro wind turbines in the UK domestic sector. Energy and Buildings 40 (7), 1324-1333.

Sanderson, M. G., Wiltshire, A. J. \& Betts, R. A. 2012 Projected changes in water availability in the United Kingdom. Water Resources Research 48, W08512.

Subak, S. 2000 Climate change adaptation in the U.K. water industry: managers' perceptions of past variability and future scenarios. Water Resources Management 14, 137-156.

Thompson, J. R. 2012 Modelling the impacts of climate change on upland catchments in southwest Scotland using MIKE SHE and the UKCP09 probabilistic projections. Hydrology

Research 43 (4), 507-530.

UK Meteorological Office 2006 MIDAS Land Surface Station data (1853-current) [internet]. NCAS British Atmospheric Data Centre. http://badc.nerc.ac.uk/view/badc.nerc.ac.uk_ ATOM_dataent_ukmo-midas.

Wright, P. 1995 Water-resources management in Scotland. Journal of the Chartered Institution of Water and Environmental Management 9 (2), 153-163.

Zhang, X. Q. \& Hu, M. C. 2014 Effectiveness of rainwater harvesting in runoff volume reduction in a planned industrial park, China. Water Resources Management 28 (3), 671-682. 